\title{
環境発電用エネルギ一貯蔵・非接触給電システムの設計
}

\section{Design of Energy Storage and Wireless Power Transmission System for Energy Harvesting}

\author{
田代 晋久*1(正員), 脇若＼cjkstart弘之 ${ }^{* 1}$ (正員), 丸野 将太郎 ${ }^{* 1}($ 学生員)
}

Kunihisa TASHIRO (Mem.), Hiroyuki WAKIWAKA (Mem.), Shotaro MARUNO (Stu. Mem.)

\begin{abstract}
This paper presents an energy strage and wireless power transmission system for energy harvesting. This system consists of sabonius windmill, rotating module and magnetic energy harvesting module. The sabonius windmill converts the wind energy to rotation energy of both the windmill and rotating module. The rotating module also can provide the power to the magnetic energy harvesting module with magnetic energy. From experimental results, the storage enegy of the system, provided power to the load and energy losses in the system are considered. Compared with a DC generator, advantages of the system are discussed.
\end{abstract}

Keywords: energy storage device, energy harvesting, rotating module, magnetic energy harvesting module, constant loss.

\section{1 緒言}

我々の身の回りに存在する再生可能エネルギーを 回収・利用する環境発電は, 環境の変化によって発電 量が大きく変動する特徵がある。また, 太陽光発電な ど発電量が大きいものを除いて, 得られる電力が $\mu \mathrm{W} \sim$ $\mathrm{mW}$ となることも欠点として挙げられる。そのため, 電力変動に対応したエネルギー貯蔵技術や, 発電した 電力を有効利用する周辺技術が重要である。風力・水 力等の再生可能エネルギーは, 運動 (回転) エネルギ 一に変換し，発電機を直結することで磁気を介して電 気エネルギーに変換される。同様に，エネルギ一貯蔵 技術には電気, 磁気, 運動エネルギーを用いる方法が 良く知られている。代表的な実現例としてキャパシタ, SMES，フライホイールが挙げられる[1]。一方，環境 発電用のエネルギー貯蔵技術には電気エネルギーとし てキャパシタに蓄える手法以外例を見ない。

著者らは環境発電用のエネルギ一貯蔵技術の代替案 として，エネルギー貯蔵と給電をシステムと考えた安 価な装置の提案を行っている[2]。Fig. 1 にその概念図 を示す[3]。エネルギー貯蔵には回転エネルギーを用い るが, 高回転・大重量のフライホイールとは異なり $\mathrm{kW}$ 以上の電力をターゲットとしない。給電は磁気を介し て電気に変換する発電機と同じだが, 必要に応じて非 接触で電気エネルギーに変換する。回転を磁気エネル

連絡先：田代 晋久, $\bar{\top} 380-8553$ 長野県長野市若里 4-17-1, 信州大学工学部電気電子工学科, e-mail:tashiro@shinshu-u.ac.jp ${ }^{* 1}$ 信州大学
ギーに変換する回転モジュール（発電機のロータ部） は円形磁石 2 個と歯車形状の磁性体のみで構成でき, 回転軸としても利用できる。磁気を電気エネルギーに 変換する磁界発電モジュール（発電機のステータ部） はコイルと磁束収束コアで構成する。両モジュールの 距離を変えることで，供給する電力を調整できる。

発電機のロータは $\mathrm{N}$ 極 $\mathrm{S}$ 極交互の磁極により径方向 磁界の大きな変動を発生する。一方, 本装置の回転モ ジュールはそのどちらかの磁極の強弱による径方向磁 界の比較的小さな変動を発生する [4]。磁界発電モジ ユールで得られる電力は磁束密度の変化量の 2 乗に比 例するため, 本システムで給電される電力も $\mathrm{mW}$ 程度 を想定している。つまり, 変動を含む再生可能エネル ギーを, 環境発電向けの応用に合わせた電力として安 定に供給することを特徴の一つとしている。

本報告では，これまで行っていなかった再生可能工 ネルギーの回収・貯蔵・給電までをシステムとして初 めて構築した例を示し，評価を通じてその優位性を示 すことを目的とした。今回は風力を対象とし, サボニ ウス型風車を試作した。前報までに試作検討を行った 回転モジュールを回転軸に接続し，磁界発電モジュー ルを用いて給電を行うシステムとした。比較対象とし て，DC モータを発電機としてサボニウス型風車軸に 直結した場合の実験も行った。風速に対する回転数特 性, 回収 (給電) 電力特性の実測を通じ, 本システム の優位性を考察した。また，サボニウス型風車を含む システムとしての貯蔵エネルギーと損失エネルギーの 推定を試みたので報告する。 


\section{2 環境発電用エネルギ一貯蔵装置の構成}

Fig. 2 に製作した環境発電用エネルギー貯蔵装置 の外観を示す。本装置はサボニウス型風車, 回転モ ジュール，磁界発電モジュールの 3 つで構成した。

サボニウス型風車は, 風力を回転エネルギーに変 換する役割を担う。直径 $230 \mathrm{~mm}$, 長さ $300 \mathrm{~mm}$ のサ ボニウス型風車を製作した。半円筒形のアクリルを 2 つ用いてバケットを構成した。パワー係数を高め, 作動周速比の領域を拡大寸るため, バケット端板を 上下に設けた $[5]$ 。回転モジュールと共通の回転軸と なるように構成した。

回転モジュールは，回転エネルギーを磁気エネル ギーに変換する役割を担う。回転モジュールは発電 機における界磁であり, 後述の磁界発電モジュール を近づけない限りエネルギー変換は行われない。 Fig. 3 に今回製作した回転モジュールの外観図を示 す。アクリルブロックに穴を空け, 回転モジュール と磁界発電モジュールの位置決めを容易にした。回 転モジュールの中心軸と磁界発電モジュールとの距 離により給電電力の調整を行う。本報告では $0.1 \mathrm{~mW}$ オーダの給電を確認できた距離 $25 \mathrm{~mm}$ を採用した [3]。Fig. 4 に使用した回転モジュールの形状を示す。 表面磁束密度 $460 \mathrm{mT}$ のネオジム磁石 2 個を同極同 土対向させる。S45C の歯車形状磁性材料を間に挟む ことで, 磁石の反発力が吸着力に変わる。歯車形状 磁性材料の周囲には, 径方向に磁界の強弱が生まれ る。今回の形状では, 中心軸から距離 $25 \mathrm{~mm}$ におけ る磁界の強弱の変動は, $10 \mathrm{mT}$ 程度となることを報 告している[4]。

磁界発電モジュールは, 磁気エネルギーを電気エネ ルギーに変換し，給電を行う役割を担う。Fig. 5 に使 用した磁束収束コアの外観を示す。磁性巻心中央の長 さ $5 \mathrm{~mm}$, 深さ $5 \mathrm{~mm}$ の狭窄部にコイルを巻いた。コイ ル寸法は長さ $5 \mathrm{~mm}$, 内径 $10 \mathrm{~mm}$, 外径 $20 \mathrm{~mm}$, 巻数 450 turn の Brooks コイル形状である[3]。実測されたイ ンダクタンスは $21.42 \mathrm{mH}$, コイル抵抗は $12.57 \Omega$ であ った。コイルのリアクタンス成分が十分無視できる場 合, 最大電力供給の定理よりコイル抵抗 $R(\Omega)$ と同程 度の負荷抵抗 $R_{\mathrm{L}}(\Omega)$ に対し最大の電力 $W(\mathrm{~W})$ を供給で きる。

$$
W=V_{\text {out }}^{2} / R_{\mathrm{L}}=V_{\text {in }}^{2} / 4 R \quad(\mathrm{~W})
$$

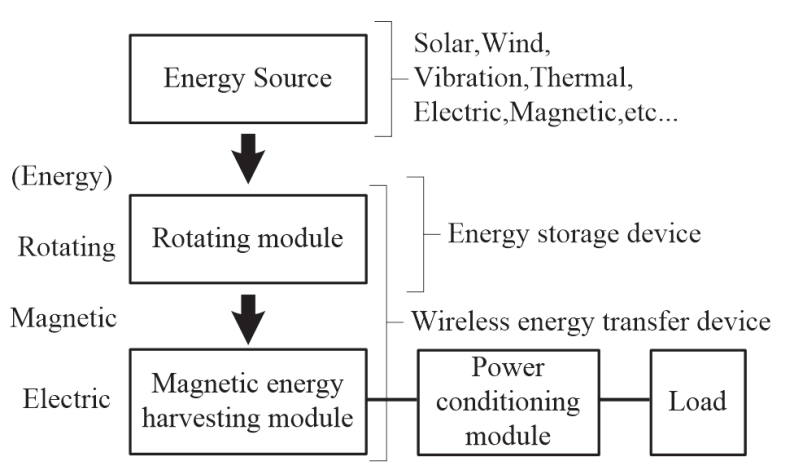

Fig. 1 Concept of energy storage device for energy harvesting.

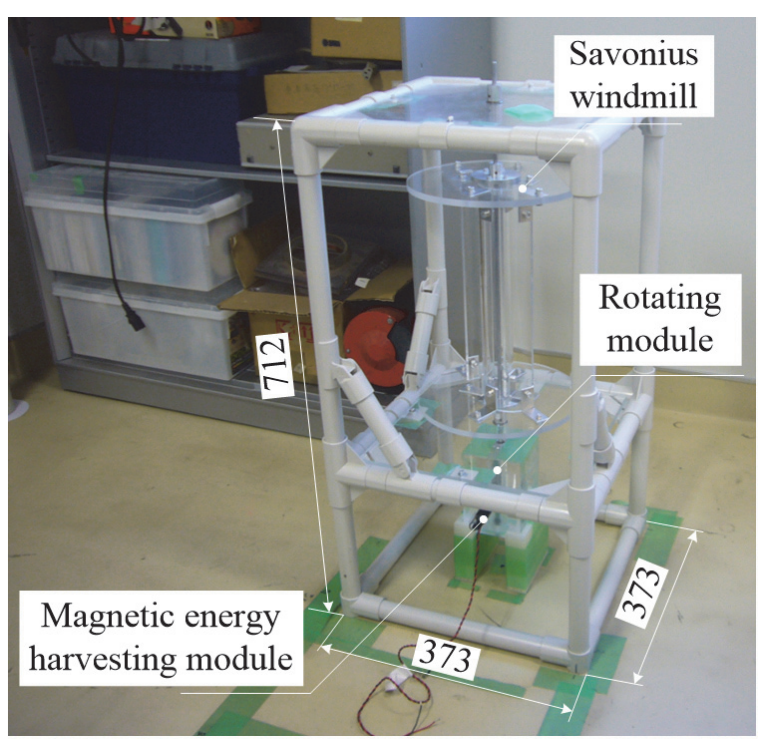

Fig. 2 Appearance of energy storage device for energy harvesting (Unit:(mm)).

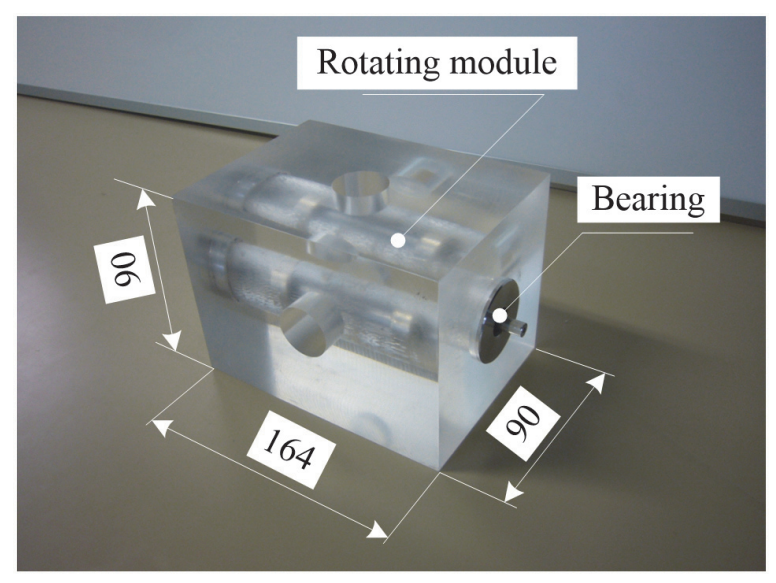

Fig. 3 Appearance of the jig to insert magnetic energy harvesting module (Unit:(mm)). 
ここで， $V_{\text {out }}(\mathrm{V})$ は負荷抵抗の両端電圧， $V_{\text {in }}(\mathrm{V})$ はコイ ル両端の開放電圧として計測できる。

\section{3 貯蔵・損失エネルギーの算出}

\section{1 貯蔵エネルギー}

前報[6]と同様に, 次式で示すフライホイールの貯蔵 エネルギーの計算式[1]を用いて, エネルギー貯蔵装置 の貯蔵エネルギー $P_{\mathrm{s}(\text { Calculated })}(\mathrm{J})$ を推定した。

$$
P_{\text {s(Calculated })}=0.5 J \omega^{2}
$$

ここで, $J\left(\mathrm{~kg} \cdot \mathrm{m}^{2}\right)$ はサボニウス型風車と回転モジュ ールを合わせた慣性モーメント， $\omega(\mathrm{rad} / \mathrm{s})$ は回転角 速度である。 $J$ を推定できれば任意の回転角速度 $\omega$ に対して $P_{\mathrm{s}(\text { Calculated })}$ を算出できる。

Fig. 6 に示す風速に対する回転数特性の概略図を 用いて $J$ の推定方法を説明する。一定の風速 $v_{\mathrm{a}}(\mathrm{m} / \mathrm{s})$ により, 回転角速度 $\omega_{\mathrm{a}}(\mathrm{rad} / \mathrm{s})$ で $P_{\mathrm{a}}(\mathrm{J})$ のエネルギー 貯蔵が行えている平衡状態を考える。この状態から, $W(\mathrm{~W})$ の一定電力をエネルギー貯蔵装置から外部へ 供給する。その結果, 回転角速度 $\omega_{\mathrm{b}}(\mathrm{rad} / \mathrm{s})$ で $P_{\mathrm{b}}(\mathrm{J})$ のエネルギー貯蔵が行える平衡状態に移行したと仮 定する。貯蔵エネルギーの減少分 $\Delta P(J)$ は式(2)を用 いて次式で定義できる。

$$
\Delta P=P_{\mathrm{a}}-P_{\mathrm{b}}=0.5 J\left(\omega_{\mathrm{a}}^{2}-\omega_{\mathrm{b}}^{2}\right) \quad(\mathrm{J})
$$

回転数 $r_{\mathrm{a}}(\mathrm{rpm}), r_{\mathrm{b}}(\mathrm{rpm})$ を用いて変形すると次式を 得る。

$$
\Delta P=0.5 J \cdot\left(\frac{2 \pi}{60}\right)^{2} \cdot\left(r_{\mathrm{a}}^{2}-r_{\mathrm{b}}^{2}\right) \quad(\mathrm{J})
$$

上式を変形すると，Jは次式で記述できる。

$$
J=\Delta P /\left\{0.5 \cdot\left(\frac{2 \pi}{60}\right)^{2} \cdot\left(r_{\mathrm{a}}^{2}-r_{\mathrm{b}}^{2}\right)\right\} \quad\left(\mathrm{kg} \cdot \mathrm{m}^{2}\right)
$$

貯蔵エネルギーの減少分 $\Delta P(\mathrm{~J})$ は 1 秒当たりの供給 電力 $W(\mathrm{~W})$ 力ら算出できる。例えば, 内部抵抗 $R$ の発 電機に負荷抵抗 $R_{\mathrm{L}}$ を接続することで一定電力を取り 出せる。エネルギ一貯蔵装置から供給される電力 $W$ の 大部分は $R$ と $R_{\mathrm{L}}$ で消費されると仮定できる。 $W$ は $R_{\mathrm{L}}$ の両端電圧実測により算出できる。これより，1 秒当 たりの消費電力量, すなわち貯蔵エネルギーの減少分

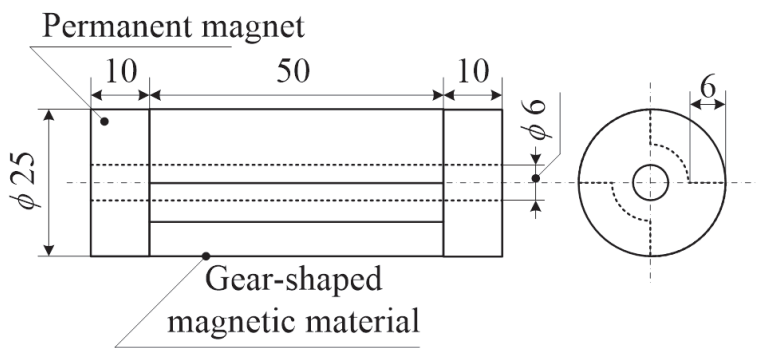

Fig. 4 Size of rotating module (Unit:(mm)).

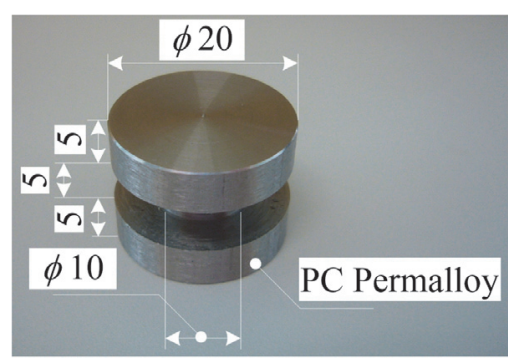

Fig. 5 Magnetic flux concentration core (Unit:(mm)).

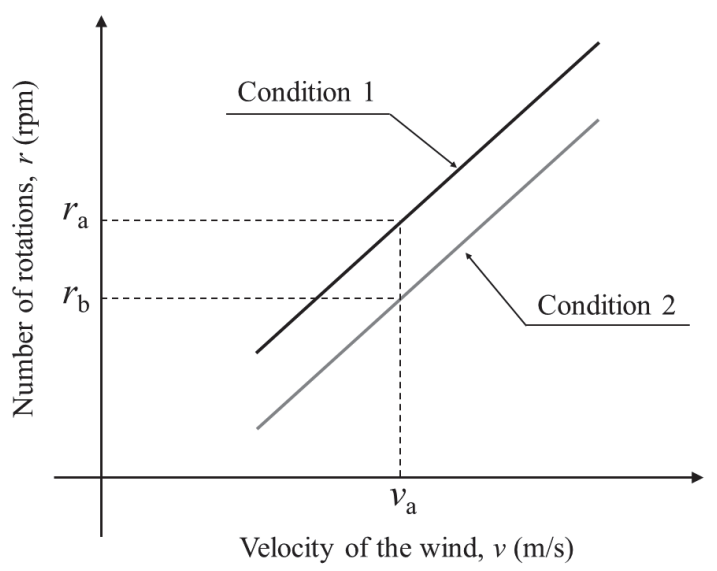

Fig. 6 Relationship between number of rotations, wind velocity and energy loss.

$\Delta P(\mathrm{~J})$ は $W \times 1(\mathrm{~J})$ として算出できる。負荷抵抗接続の有 無による回転数が $r_{\mathrm{a}}, r_{\mathrm{b}}$ に対応し，実測できる。式(5) の右辺が求まるため，Jを算出できる。

\section{2 損失エネルギー}

磁界発電モジュールや発電機に負荷を接続しない 場合，内部のコイルに電流は流れない。一方，磁性材 料に磁界が鎖交すると, 磁性体内部に発生する渦電流 損や鉄損により損失エネルギーが発生する。磁界発電 モジュールと発電機の有無による回転数变化の実測值 
より，貯蔵エネルギーに対する損失エネルギーの割合 $\varepsilon(\%)$ を次式で定義し, 評価を行った。

$$
\varepsilon=\left(1-\frac{P_{\mathrm{b}}}{P_{\mathrm{a}}}\right) \times 100=\left(1-\frac{\omega_{\mathrm{b}}^{2}}{\omega_{\mathrm{a}}^{2}}\right) \times 100 \quad(\%)
$$

\section{4 実験方法}

\section{1 風速に対する回転数特性}

Fig. 7 に環境発電用エネルギー貯蔵装置による実験 概略図を示す。風洞装置から風を発生させ，サボニウ ス型風車の回転数 $r(\mathrm{rpm})$ をタコメータ $(\mathrm{HIOKI}$, FT3405)で測定した。風速 $v(\mathrm{~m} / \mathrm{s})$ は 5.2, 5.8, $6.1 \mathrm{~m} / \mathrm{s}$ の 3 種類で行った。本装置の比較対象として, DC モ 一タ (Portescap, 22V28213E201)を発電機として回転軸 に直結した実験も行った。磁界発電素子あるいは発電 機における負荷抵抗の有無, および両者が無い無負荷 の 5 通りをパラメータとし, 実験を行った。発電機の 内部抵抗実測值は $11.9 \Omega$ であり, 磁界回収モジュール のコイル抵抗と同程度であった。そのため, 両者とも $12 \Omega$ の負荷を接続した。

\section{2 風速に対する回収電力特性}

前項と同じく，磁界発電モジュールあるいは発電機 に接続した $12 \Omega$ の負荷 $R_{\mathrm{L}}$ に対する給電特性を測定し た。風速 $v(\mathrm{~m} / \mathrm{s})$ は $5.2,5.8,6.1 \mathrm{~m} / \mathrm{s}$ の 3 種類で行った。 磁界発電モジュールの負荷両端電圧 $V_{\text {out }}$ は FFT アナラ イザ(小野測器，CF-930)で対応する周波数の電圧を測 定した。発電機両端の負荷両端電圧 $V_{\text {out }}$ はテスタ (FLUKE 187, およびYOKOGAWA 73202)を用い，直流 電圧を測定した。式(1)より回収電力 $W$ を算出した。

\section{3 貯蔵・損失エネルギーの算出}

発電機を直結し，12 $\Omega$ の負荷 $R_{\mathrm{L}}$ の有無による回転 数 $r_{\mathrm{a}}, r_{\mathrm{b}}$ をタコメータで測定した。負荷両端電圧 $V_{\text {out }}$ をテスタを用いて測定し， $\Delta P$ を算出した。式(5)を用 いて $J$ を算出し, 式(2)を用いて $P_{\mathrm{s}(\text { Calculated })}$ を推定した。 同様に, 磁界発電モジュールと発電機の有無による回 転数 $r_{\mathrm{a}}, r_{\mathrm{b}}$ をタコメータで測定した。式(6)を用いて貯 蔵エネルギーに対する損失エネルギーの割合 $\varepsilon \quad(\%)$ を算出した。同様に, 式(4)を用いて磁界発電モジュー ルと発電機の有無による 1 秒当たりの損失エネルギー $\Delta P(\mathrm{~J})$ の算出を行った。

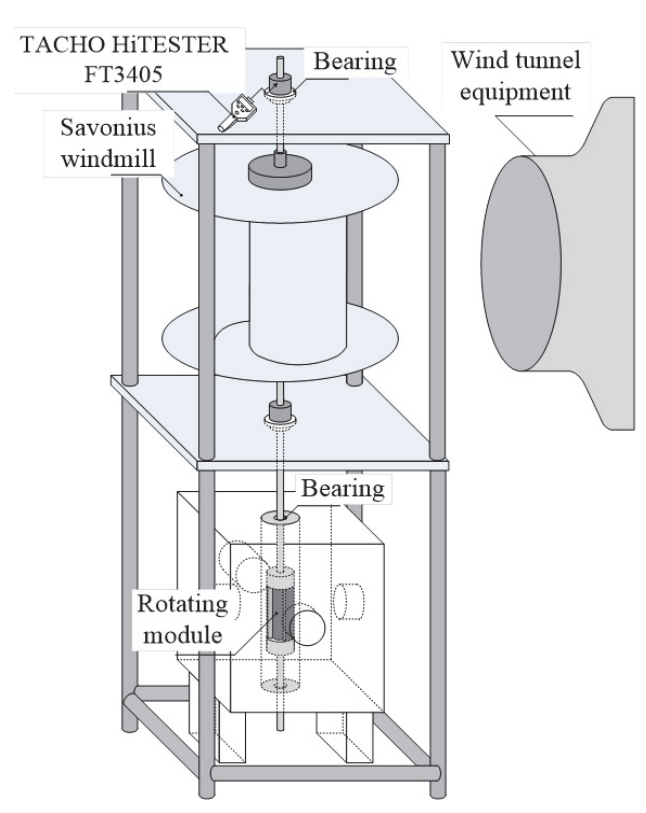

Fig. 7 Experimental setup.

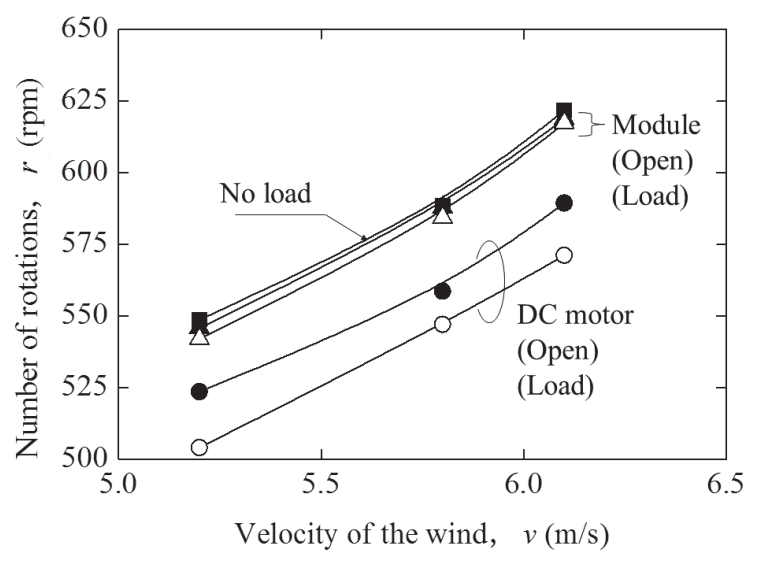

Fig. 8 Measured number of rotations as a function wind velocity.

\section{5 実験結果}

\section{1 風速に対する回転数特性}

Fig. 8 に風速に対する回転数特性の実測值を示す。 丸, 三角, 四角のプロットはそれぞれ発電機(DC motor), 磁界発電モジュール(Module), および両者を設置しな い無負荷時(No load)の実測值を示す。なお，負荷抵抗 接続時は中抜きのマーカー，端子開放時は塗りつぶし のマーカーで記載した。回転数の実測值は 5 回測定し た平均值を採用した。なお無負荷時における平均值を 基準とした偏差の最大值を算出したところ, どの風速 においても $0.27 \%$ 以下となった。 
発電機を回転軸に直結することで，負荷抵抗接続の 有無によらず，無負荷時の回転数に対して顕著な回転 数低下を確認した。端子開放時では $32.4 \mathrm{rpm}$, 負荷接 続時では $50.6 \mathrm{rpm}$ の最大となる回転数低下が見られた。 対応する風速はいずれも $6.1 \mathrm{~m} / \mathrm{s}$ であった。

磁界発電モジュールを配置した場合，無負荷時と 比較しても顕著な回転数低下は見られなかった。回 転数低下の最大值は, 端子開放時では $3.0 \mathrm{rpm}$, 負荷 抵抗接続時では $6.6 \mathrm{rpm}$ の回転数低下にとどまった。 対応寸る風速は $6.1 \mathrm{~m} / \mathrm{s}$ と $5.2 \mathrm{~m} / \mathrm{s}$ であった。電力供 給を行わない場合でも, 発電機では顕著な貯蔵エネ ルギーの減少につながる回転数低下となった。一方, 磁界発電モジュールではその $1 / 10$ 以下となる回転数 低下に収まった。

\section{2 風速に対寸る回収電力特性}

Fig. 9 に風速に対する回収電力特性を示す。回収 電力の実測值は 5 回測定した平均值を採用した。今 回検討した風速の範囲では, 発電機において最大 20 $\mathrm{mW}$ の回収電力が得られた。一方, 磁気エネルギー 回収モジュールでは $0.1 \mathrm{~mW}$ 程度の安定した回収電 力が得られた。どちらの場合でも, 環境発電におけ る再生可能エネルギーの変動に伴う供給電力の低減 を緩和する, 電力調整回路の役割を担えることを確 認した。

発電機で給電電力を変更する場合, 機械的損失を 含むギアによる回転数変換を行う必要がある。一方, 磁界発電モジュールの場合, 中心軸からの距離を変 更することで対応できる。参考として, 距離が 16, 20, $35 \mathrm{~mm}$ の時の実測を行った所, 風速によらず 0.7, 0.2, $0.01 \mathrm{~mW}$ 程度の回収電力が得られた。16 mm の距離 に磁界発電モジュールを配置した場合, 開放時でも $10 \mathrm{rpm}$ 程度の回転数低下を確認した。距離を縮める と, 磁界発電モジュールの磁束収束コアに鎖交する 磁束が増加する。発電機の場合，ロータとステータ 間の距離は可能な限り狭く設計されている。つまり, 負荷抵抗を接続しない場合でも, 磁束が磁性体に鎖 交することで， 1 秒当たりの損失エネルギー $\Delta P(\mathrm{~J})$ つ まり電力損失 $W_{\text {Loss }}(\mathrm{W})$ が発生していると考察した。

\section{3 貯蔵・損失エネルギーの算出}

一例として, 風速 $5.2 \mathrm{~m} / \mathrm{s}$ 時の条件を用いて $J$ を算 出した。これまでの実験結果を用いて式(5)の右辺に 代入すると, 算出された $J$ は $2.34 \times 10^{-4}\left(\mathrm{~kg} \cdot \mathrm{m}^{2}\right)$ とな

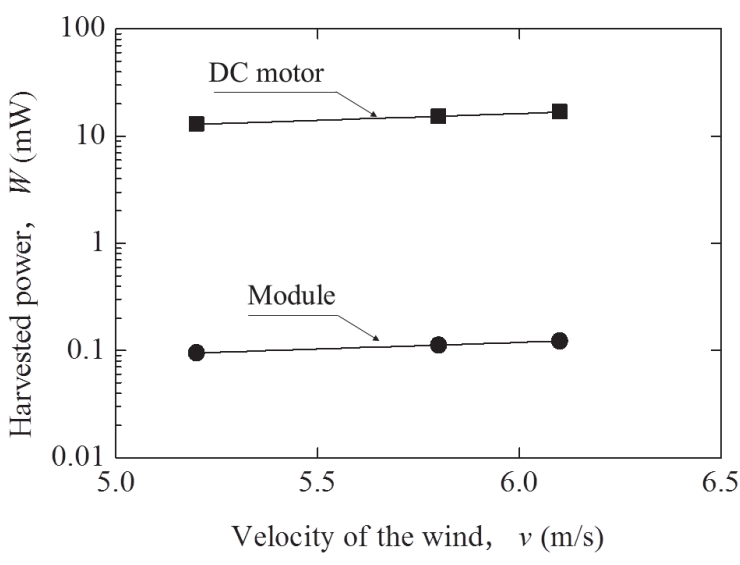

Fig. 9 Harvested power as a function of wind velocity.

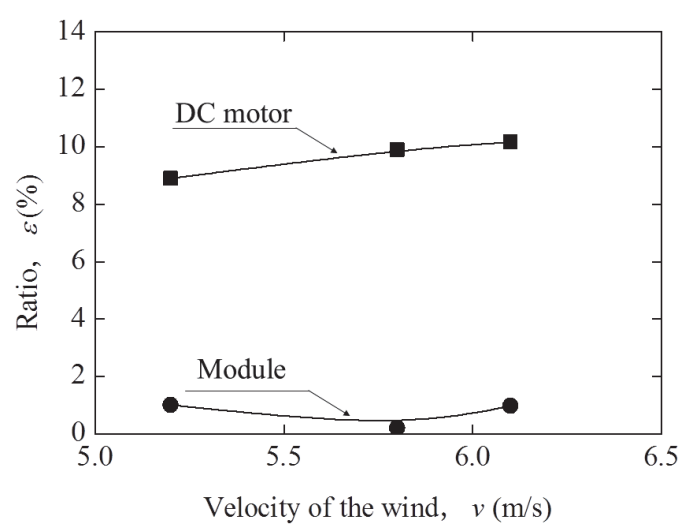

Fig. 10 Ratio of constant loss energy to storage energy as a function of wind velocity.

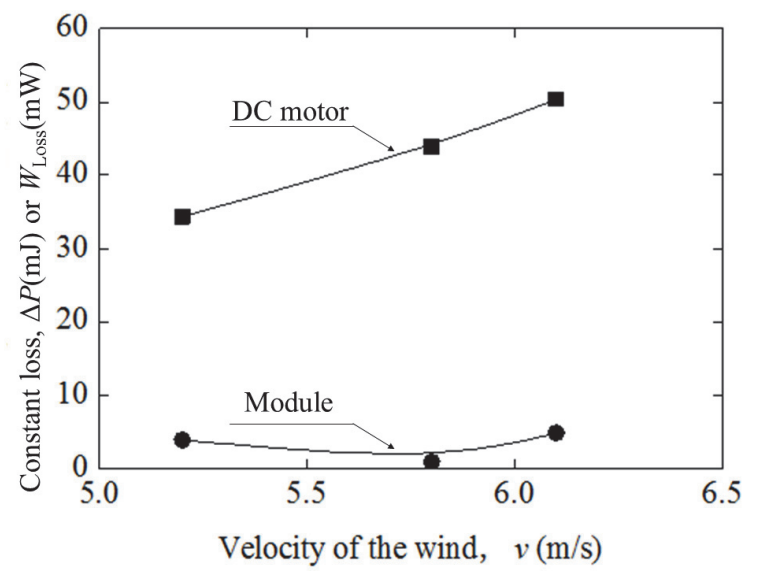

Fig. 11 Constant loss as a function of wind velocity. 
つた。風速 5.2, $5.8,6.1 \mathrm{~m} / \mathrm{s}$ に対する無負荷時の回 転数の平均值は, $548,588,621 \mathrm{rpm}$ であった。式(2) より, 対応する貯蔵エネルギー $P_{\mathrm{s}(\text { Calculated) }}$ は $0.38,0.44$, $0.49 \mathrm{~J}$ と算出された。

Fig. 10 に貯蔵エネルギーに対する損失エネルギー の割合 $\varepsilon(\%)$ を算出した結果を示す。発電機を直結す るだけで, 貯蔵エネルギーの $10 \%$ 程度が失われるこ とを確認した。一方, 磁界発電モジュールを配置す ると, 貯蔵エネルギーの $1 \%$ 程度の損失であること が判明した。

Fig. 11 に端子開放時の磁界発電モジュールと発電機 の有無による 1 秒当たりの損失エネルギー $\Delta P(\mathrm{~J})$ の算 出を行った。この值は, 前節の考察より磁束収束コア （磁性体）による電力損失 $W_{\text {Loss }}(\mathrm{W})$ とも考えることが できる。それぞれ 1 秒あたり損失エネルギーは最大で $5 \mathrm{~mJ}, 50 \mathrm{~mJ}$,つまり $5 \mathrm{~mW}, 50 \mathrm{~mW}$ の電力損失に相当 した。発電機と比較し, 磁界発電モジュールの損失は 1/10 以下であり, 環境発電用途への優位性を確認した。

\section{6 結言}

本報告では, 風力エネルギーの回収・貯蔵・給電ま でをシステムとして初めて構築した例を示し, 評価を 通じて環境磁界発電用エネルギ一貯蔵装置の優位性を 示した。以下に得られた成果をまとめる。

(1) 風速 5.2，5.8, $6.1 \mathrm{~m} / \mathrm{s}$ に対し，548, 588, $621 \mathrm{rpm} の$ 回転数が得られた。対応する貯蔵エネルギーは 0.38 , $0.44,0.49 \mathrm{~J}$ と推定した。

(2) $0.1 \mathrm{~mW}$ の電力を安定に給電できることが分かった。 また, 回転モジュールとの距離により給電可能電力 を調整できることも確認した。ギアによる回転数変 換を必要とする発電機に比べ優位性があると結論 付けた。

(3) 発電機を直結した場合, 給電を行わない場合でも 顕著な回転数低下を確認した。つまり微弱な風力が 存在するのに, 風車が回らない状況を生久出す。本 システムでは, 微弱な風力でも磁界発電モジュール の距離を調整することで, 見合ったエネルギー回 収・貯蔵・給電を行う利用形態を提案できる。

(4) 磁界発電モジュールに変動磁界が鎖交することに よる損失エネルギーは, 貯蔵エネルギーに対して $1 \%$ 程度, 発電機と比較し $1 / 10$ 以下の值であった。 貯蔵エネルギーの有効利用の点で優位性を示した。
本システムの応用例の一つとして, 風力等の再生可 能エネルギーの存在の有無を情報として把握するため の無線センサネットワークが挙げられる。XBee 子機 であれば 1 回の通信あたり $1.53 \mathrm{~mJ}$ であり[7], 本シス テムの貯蔵エネルギーで十分賄える。1 F のキャパシ 夕を例に比較すると， $0.5 \mathrm{~J}$ のエネルギーに必要な電圧 は $1 \mathrm{~V}$ 程度である。体積当たりのエネルギー密度では, 市販のキャパシタに現時点で遠く及ばない。一方, 発 電機等で電力変換を行い, キャパシタへ蓄電し利用す るような形態と比較すると, 本システムは回収可能な エネルギーを無䭾なく利用できる点において優位性が あると考えられる。

\section{謝辞}

本研究の一部は一般社団法人信州大学工学部若里会 の補助を受けて行われた。風洞実験は, 信州大学工学 部環境機能工学科飯尾昭一郎准教授の所有する装置を 利用させていただいた。ここに感謝の意を表する。

(2014 年 3 月 14 日受付, 2014 年 9 月 25 日再受付)

\section{参考文献}

[1] 吉田隆, エネルギーの貯蔵・輸送, エヌ・ティー・エス, p.73, 2008.

[2] 田代晋久, エネルギー貯蔵装置, 特願 2011-236368.

[3] 田代晋久, 脇若弘之, 丸野将太郎, 対向配置磁石型非接 触エネルギー伝送装置の試作, 日本 $A E M$ 学会誌, Vol.21, No.2, pp.203-208, 2013.

[4] 丸野将太郎, 田代晋久, 脇若弘之, 対向配置磁石を用い た交流磁界発生装置用磁性材料形状の最適化, 電気学会 マグネティックス研究会資料, MAG-12-84, pp.17-20, 2012.

[5] 牛山泉, 長井浩, 篠田仁吉, サボニウス風車の最適設計 形状に関する研究, 日本機械学会論文集(B 編), 52 巻, 480 号, pp.2973-2982, 1986.

[6] 丸野将太郎, 田代晋久, 脇若弘之, 環境発電用回転モジ ユールの貯蔵エネルギーの推定, マグネティックス・リ ニアドライブ合同研究会資料, MAG-13-36/LD-13-40, pp.47-52, 2013.

[7] 池上梓, 服部玄也, 島田翔一郎, 小嶋宏明, 田代晋久, 脇若弘之, 環境磁界発電を用いた XBee による無線通信 の検討, 第 26 回「電磁力関連のダイナミクス」シンポジ ウム講演概要集, 21Bp10, pp. 120-123, 2014. 